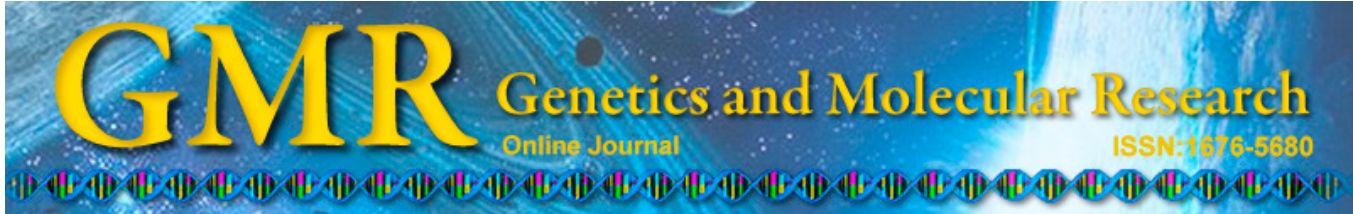

\title{
Comparative cytogenetic mapping of rRNA genes among naked catfishes: implications for genomic evolution in the Bagridae family
}

\author{
W. Supiwong ${ }^{1,3}$, T. Liehr ${ }^{1}$, M.B. Cioffi ${ }^{2}$, A. Chaveerach ${ }^{3,5}$, N. Kosyakova ${ }^{1}$, \\ X. Fan ${ }^{1}$, T. Tanee ${ }^{4,5}$ and A. Tanomtong ${ }^{3}$ \\ ${ }^{1}$ Jena University Hospital, Friedrich Schiller University, \\ Institute of Human Genetics, Jena, Germany \\ ${ }^{2}$ Departamento de Genética e Evolução, Universidade Federal de São Carlos, \\ São Carlos, SP, Brasil \\ ${ }^{3}$ Department of Biology, Faculty of Science, Khon Kaen University, \\ Muangkhonkaen District, Khon Kaen, Thailand \\ ${ }^{4}$ Faculty of Environment and Resource Studies, Mahasarakham University, \\ Kantarawichai District, Mahasarakham, Thailand \\ ${ }^{5}$ Genetics and Environmental Toxicity Research Group, Khon Kaen University, \\ Khon Kaen, Thailand
}

Corresponding author: A. Chaveerach

E-mail: raccha@kku.ac.th

Genet. Mol. Res. 13 (4): 9533-9542 (2014)

Received October 17, 2013

Accepted May 7, 2014

Published November 12, 2014

DOI http://dx.doi.org/10.4238/2014.November.12.2

\begin{abstract}
In the present study, the karyotype and chromosomal characteristics of 9 species of the Bagridae fish family were investigated using conventional Giemsa staining as well as dual-color fluorescence in situ hybridization to detect the 18S and 5S rDNA sites. In addition to describing the karyotype of several Bagridae catfishes, we established molecular cytogenetic techniques to study this group. The 9 species contained a diploid chromosomal number, varying from 50 (Pseudomystus siamensis) to 62 (Hemibagrus wyckii), while none contained heteromorphic sex chromosomes. 18S rDNA sites were detected in only 1 chromosomal pair among all species evaluated. However, 3 different patterns were observed for the distribution of the 5S rDNA: 2 sites were found in the genus Mystus and in P. siamensis,
\end{abstract}


multiple sites were observed in the genus Hemibagrus, and a syntenic condition for the 18S and 5S rDNA sites was identified in $H$. wyckii. The extensive variation in the number and chromosomal position of rDNA clusters observed among these Bagridae species may be related to the intense evolutionary dynamics of rDNA-repeated units, which generates divergent chromosomal distribution patterns even among closely related species. In summary, the distribution of repetitive DNA sequences provided novel, useful information regarding the evolutionary relationships between Bagridae fishes.

Key words: Fluorescence in situ hybridization; Freshwater fishes; Karyotype evolution; Molecular cytogenetics; Ribosomal DNA

\section{INTRODUCTION}

Bagridae is a family of catfishes found in Africa and Asia, from Japan to Borneo, and consists of approximately 200 species (Ferraris, 2007). These species belong to the order Siluriformes and are commonly known as bagrid or naked catfishes (Nelson, 2006). They range in size from $30 \mathrm{~mm}$ to $200 \mathrm{~cm}$ and can be found in many diverse habitats, including alkaline lakes, small acidic ditches, flowing hill streams, and some of the largest rivers in the world (Linder, 2002). Bagridae is the largest family of Thai catfishes, with 5 genera and 27 species recorded (Rainboth, 1996; Vidthayanon, 2005; Ferraris, 2007). These species play an important role in the national economic value of the country, as they are kept in aquaria and contribute heavily to the aquaculture industry (Vidthayanon, 2005).

Approximately 44 of the 200 species in the Bagridae family have been studied cytogenetically, with their diploid numbers ranging from 44 chromosomes in Coreobagrus brevicorpus (Kim et al., 1982) to 80 chromosomes in Batasio havmolleri (Magtoon and Donsakul, 2009). In addition, many species show intra-specific variation in their $2 \mathrm{n}$ and chromosomal types. However, conventional cytogenetic analysis has been applied to determine the chromosome number and karyotype composition of only a few species in this family. Very few studies have used argyrophilic nucleolar organizer region staining and $\mathrm{C}$-staining techniques (Arai, 2011), while molecular cytogenetic techniques have never been utilized.

The molecular organization and cytogenetic locations of ribosomal RNA (rDNA) repeats have been analyzed in a large number of fish species (Cioffi and Bertollo, 2012). These studies demonstrated the enormous potential that the investigation of repetitive DNAs offers to extend the knowledge of karyotype differentiation in fishes. In higher eukaryotes, rDNA comprise 2 repetitive DNA families, the $45 \mathrm{~S}$ and the $5 \mathrm{~S}$ rDNAs. The $45 \mathrm{~S}$ rDNA is formed by tandemly repeating units composed of 3 transcribed regions, $18 \mathrm{~S}, 5.8 \mathrm{~S}$, and $28 \mathrm{~S}$ rRNA, generating regions separated by internal transcribed spacers and non-transcribed spacer (NTS) sequences (Long and Dawid, 1980). By contrast, the 5S rDNA is formed by tandemly repeated units of the 5S rRNA-coding region and an NTS sequence (Pendás et al., 1994).

In the present study, we examined the karyotypes of 9 bagrid catfishes belonging to 3 different genera (Hemibagrus, Mystus, and Pseudomystus); H. filamentus was characterized for the first time. We also determined the distribution of the 18S and 5S rDNA sites on the chromosomes. We found that major rDNA sequences were located on a single pair of chromosomes in all species, while the 5S rDNA distribution varied greatly from 1-5 chromosomal pairs. Moreover, the distribution pattern of $5 \mathrm{~S}$ rDNA co-localized with major rDNA clusters in 
the species $H$. wyckii. This pattern of distribution of the rRNA genes may be used for speciesspecific characterization and contribute to the understanding of chromosomal organization and genomic evolution in the Bagridae family. In addition, the relationship between 18S rDNA cluster stability and the large variability of the 5S rRNA genes is discussed.

\section{MATERIAL AND METHODS}

\section{Specimens, mitotic chromosome preparation, and chromosome staining}

Samples from both sexes of 9 Thailand naked catfishes from the Bagridae family were analyzed (Figure 1 and Table 1). The fishes were transferred to laboratory aquaria and kept under standard conditions for 7 days prior to the experiments. Experiments followed ethical protocols and anesthesia with clove oil was administered prior to sacrificing the animals to minimize suffering.

Mitotic chromosomes were obtained from cell suspensions of the anterior kidney using the conventional air-drying method (Nanda et al., 1995). Conventional staining was carried out using 20\% Giemsa solution for $10 \mathrm{~min}$. At least 20-30 metaphase spreads were analyzed per specimen to confirm the diploid chromosome numbers and karyotype structure. Images were captured using the CoolSNAP system software, Image Pro Plus, 4.1 (Media Cybernetics, Silver Spring, MD, USA), coupled to an Olympus BX50 microscope (Olympus Corporation, Tokyo, Japan). Chromosomes were classified as metacentric (m), submetacentric (sm), subtelocentric (st), or acrocentric (a) according to the arm ratios (Levan et al., 1964).

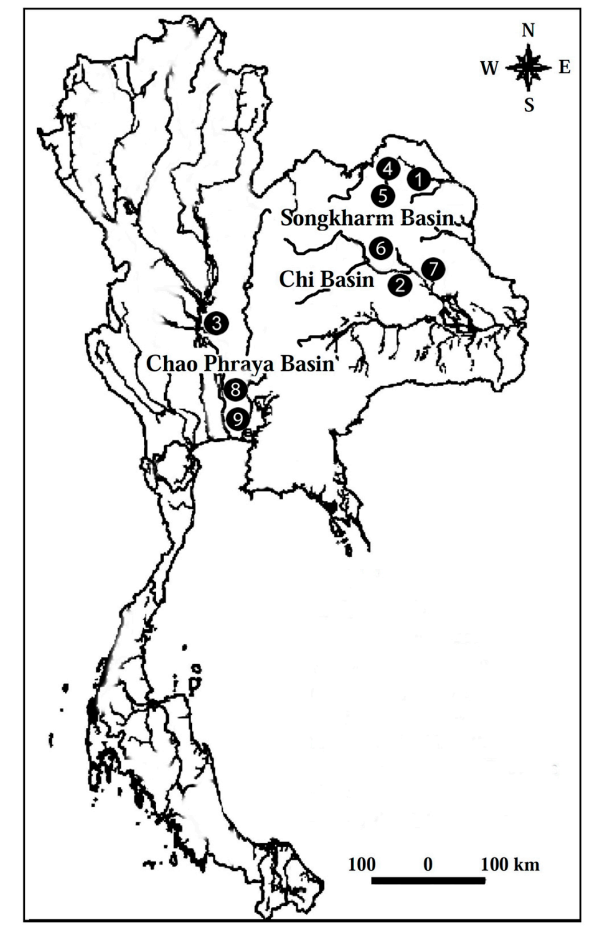

Figure 1. Collection sites of the Bagridae species analyzed from Thailand. $1=$ Hemibagrus filamentus; $2=$ Hemibagrus nemurus; 3 = Hemibagrus wyckii; $4=$ Hemibagrus wyckioides; $5=$ Mystus atrifasciatus; $6=$ Mystus multiradiatus; 7 = Mystus mysticetus; $8=$ Mystus bocourti; $9=$ Pseudomystus siamensis . 
Table 1. Collection sites of the species analyzed with the sample size, diploid numbers, and chromosomal formulas.

\begin{tabular}{|c|c|c|c|c|}
\hline Species & $\mathrm{N}$ & $2 n$ & NF & Chromosomal formula \\
\hline Hemibagrus filamentus (site 1) & 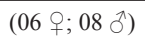 & +๐ 58 & 116 & $10 \mathrm{~m}+13 \mathrm{sm}+6 \mathrm{st} / \mathrm{a}$ \\
\hline Hemibagrus nemurus (site 2) & $(07$ 0; 07 ठె) & +क 58 & 114 & $9 \mathrm{~m}+13 \mathrm{sm}+7 \mathrm{st} / \mathrm{a}$ \\
\hline Hemibagrus wyckii (site 3) & $(04+04 \pi)$ & +人 62 & 102 & $7 \mathrm{~m}+13 \mathrm{sm}+11 \mathrm{st} / \mathrm{a}$ \\
\hline Hemibagrus wyckioides (site 4) & $(06$ 웅 05$)$ & +人 58 & 100 & $11 \mathrm{~m}+10 \mathrm{sm}+8 \mathrm{st} / \mathrm{a}$ \\
\hline Mystus atrifasciatus (site 5) & $(08$; 05 Љ) & +254 & 96 & $12 \mathrm{~m}+9 \mathrm{sm}+6 \mathrm{st} / \mathrm{a}$ \\
\hline Mystus multiradiatus & $(03$ 웅 04$)$ & +ô 54 & 96 & $9 m+12 s m+6 s t / a$ \\
\hline Mystus mysticetus & $(08$ 웅 10 ) & +人 52 & 100 & $13 \mathrm{~m}+11 \mathrm{sm}+2 \mathrm{st} / \mathrm{a}$ \\
\hline Mystus bocourti & $(04$ 우 07 ठ $)$ & +ô 56 & 100 & $11 \mathrm{~m}+11 \mathrm{sm}+6 \mathrm{st} / \mathrm{a}$ \\
\hline Pseudomystus siamensis (site 9) & $(06 \% ; 09$ ठ) & +350 & 90 & $10 \mathrm{~m}+10 \mathrm{sm}+5 \mathrm{st} / \mathrm{a}$ \\
\hline
\end{tabular}

$2 \mathrm{n}=$ diploid number; $\mathrm{NF}=$ fundamental number; $\mathrm{m}=$ metacentric chromosomes; $\mathrm{sm}=$ submetacentric chromosomes; st $=$ subtelocentric chromosomes; $\mathrm{a}=$ acrocentric chromosomes. Sites 1-9 correspond to the localization of each collection region shown in Figure 1.

\section{Chromosome probes and fluorescence in situ hybridization (FISH) experiments}

Two tandemly arrayed DNA sequences isolated from the genome of an Erythrinidae fish species, Hoplias malabaricus, were used as probes. The first probe contained a 5S rDNA repeat copy and included $120 \mathrm{bp}$ of the $5 \mathrm{~S}$ rRNA-transcribing gene and $200 \mathrm{bp}$ of the NTS sequence (Martins et al., 2006). The second probe corresponded to a 1400-bp segment of the $18 \mathrm{~S}$ rRNA gene obtained via polymerase chain reaction from nuclear DNA (Cioffi et al., 2009). The $5 \mathrm{~S}$ and $18 \mathrm{~S}$ rDNA probes were cloned into plasmid vectors and propagated in DH5 $\alpha$ Escherichia coli competent cells (Invitrogen, Carlsbad, CA, USA).

The $5 \mathrm{~S}$ and $18 \mathrm{~S}$ rDNA probes were labeled with Spectrum Orange-dUTP and Spectrum Green-dUTP, respectively, using nick translation according to manufacturer recommendations (Roche, Mannheim, Germany).

FISH was performed under high-stringency conditions on mitotic chromosome spreads (Pinkel et al., 1986). Metaphase chromosome slides were incubated with $40 \mu \mathrm{g} / \mathrm{mL}$ RNase for $1 \mathrm{~h}$ at $37^{\circ} \mathrm{C}$. After denaturation of chromosomal DNA in $70 \%$ formamide $/ 2 \mathrm{X} \mathrm{SSC}$ at $70^{\circ} \mathrm{C}$, the spreads were incubated in $2 \mathrm{X} \mathrm{SSC}$ for $4 \mathrm{~min}$ at $70^{\circ} \mathrm{C}$. The hybridization mixture composed of $2.5 \mathrm{ng} / \mu \mathrm{L}$ probes, $2 \mu \mathrm{g} / \mu \mathrm{L}$ salmon sperm DNA, $50 \%$ deionized formamide, and $10 \%$ dextran sulfate was added to the slides, and hybridization was performed overnight at $37^{\circ} \mathrm{C}$ in a moist chamber containing 2 X SSC. The post-hybridization wash was carried out using $1 \mathrm{X}$ SSC for 5 $\mathrm{min}$ at $65^{\circ} \mathrm{C}$. A final wash was performed at room temperature in 4X SSCT for $5 \mathrm{~min}$. Finally, the slides were counterstained with 4'6-diamidino-2-phenylindole and mounted in an antifade solution (Vector, Burlingame, CA, USA). Images were captured using a fluorescence microscope (Olympus BX51) equipped with a CCD camera (Olympus DP70).

\section{RESULTS}

\section{Karyotypes}

We analyzed 9 species belonging to 3 genera in the Bagridae family. The diploid numbers varied from 50 (as found in P. siamensis) to 62 chromosomes (as found in $H$. wyckii), while the fundamental numbers varied from 90 (P. siamensis) to 116 chromosomes $(H$. filamentus) (Figure 2). Some species in the same genus presented the same $2 \mathrm{n}$ value but showed differences in their fundamental number values. Variations in the number of $\mathrm{m}$, sm, and st/a 
chromosomes were observed among species, even within the same genus (Table 1). In all species analyzed, no differences between male and female karyotypes were observed.

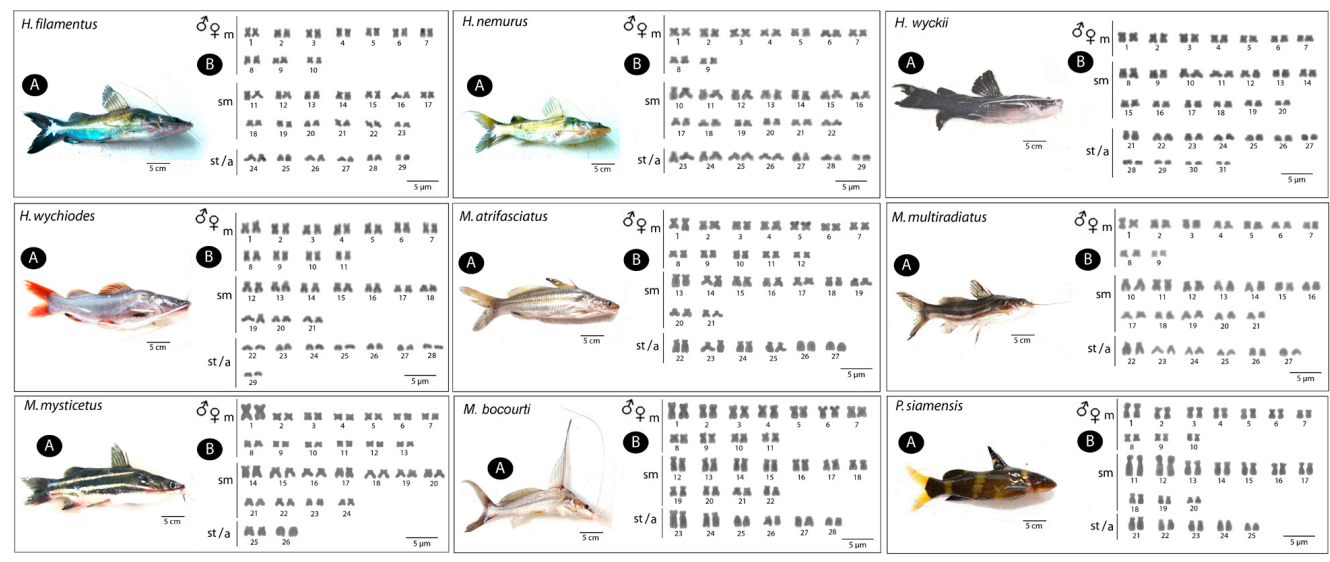

Figure 2. Fish images (A) and karyotypes $(\mathbf{B})$ of Bagridae fishes after Giemsa staining. Scale bars $=5 \mu \mathrm{m}$.

\section{Physical chromosome mapping of 5S and 18S rDNA sequences}

The probe for the $18 \mathrm{~S}$ rDNA hybridized to 1 chromosomal pair in all species analyzed, preferentially located on the subtelomeric/telomeric region of the short arms, except for $H$. wyckii and P. siamensis, which showed interstitial $18 \mathrm{~S}$ rDNA sites on the long arm of an $\mathrm{m}$ chromosome (Figure 3).
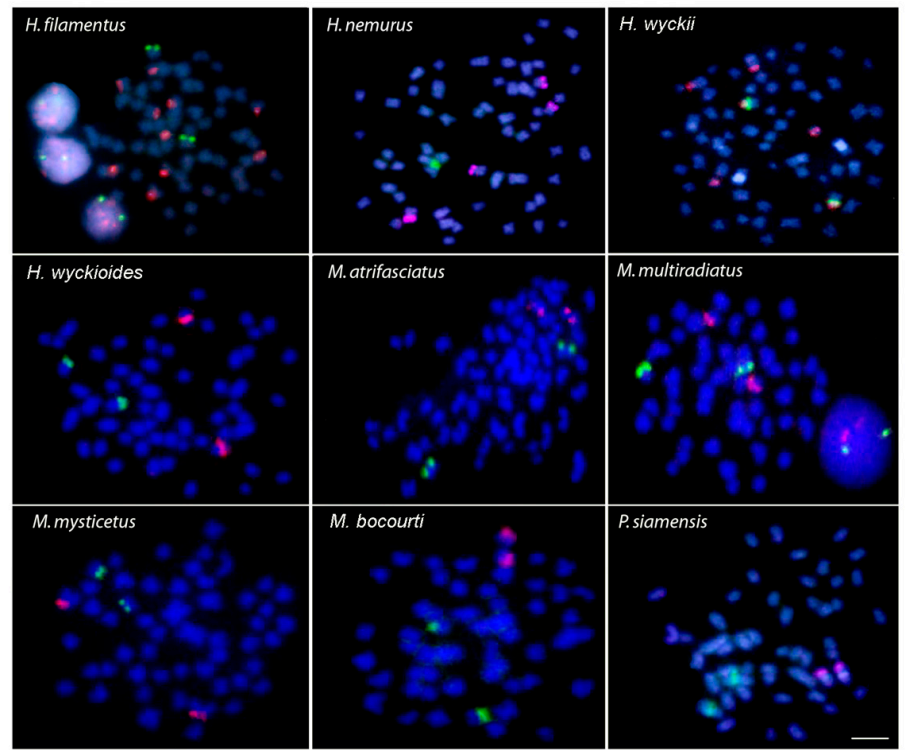

Figure 3. Fluorescence in situ hybridization of $5 \mathrm{~S}$ (red) and 18S (green) rDNA sequences in the mitotic metaphase chromosomes of 9 Bagridae catfishes. Scale bar $=5 \mu \mathrm{m}$. 
By contrast, the location of $5 \mathrm{~S}$ rDNA sequences varied widely among species. The following numbers of $5 \mathrm{~S}$ rDNA-bearing chromosomes were identified in each species analyzed: 1 pair in H. wyckioides, M. atrifasciatus, M. bocourti, M. multiradiatus, M. mysticetus, and $P$. siamensis, 2 pairs in $H$. nemurus, 3 pairs in $H$. wyckii, and 5 pairs in $H$. filamentus. The 5S rDNA loci were adjacent to the telomeres of the short arm of the chromosomes in $\mathrm{H}$. filamentus, H. nemurus, P. siamensis, M. bocourti, and M. mysticetus. Synteny between the $18 \mathrm{~S}$ and 5S rDNA sites was found only in $H$. wyckii (Figure 3).

\section{DISCUSSION}

In this study, we determined the karyotypes of several Bagridae catfishes, describing the H. filamentus karyotype for the first time. In addition, we established the use of molecular cytogenetic techniques in Bagrid catfishes by analyzing the distribution of rRNA genes.

\section{Karyotypes}

All 9 species, except $H$. filamentus and M. mysticetus, exhibited $2 \mathrm{n}$ values that agreed with previous reports (Donsakul, 2000, 2001, 2002). H. filamentus showed the same diploid number (58) as H. wyckioides, H. nemurus (Donsakul, 2001), and H. menoda (Das and KhudaBukhsh, 2007), although there were some minor differences between the number of $\mathrm{m}, \mathrm{sm}$, and st/a chromosomes. M. mysticetus presented a $2 \mathrm{n}$ value of 52, differing from the results of a previous study, which found $2 \mathrm{n}$ values of 50 (Donsakul, 2000). Intra-specific variation of the $2 \mathrm{n}$ values in this species suggests a Robertsonian translocation or centric fusion between acrocentric pairs during the karyotype evolution of this species, forming an $\mathrm{m}$-sm chromosome. In fact, many species in the Bagridae family, such as $H$. menoda, H. nemurus, M. vittatus, and Sperata seenghala, demonstrate intra-specific variation in their $2 \mathrm{n}$ values (Arai, 2011). Moreover, this phenomenon has been reported for other catfish species from different families (Kavalco et al., 2005; Rosa et al., 2012). Similarly to other species in the Bagridae family of Thailand, no heteromorphic sex chromosomes were identified among the 9 species analyzed. By contrast, the $M$. gulio and $M$. tengara Bagrid catfishes in India have differentiated sex chromosome systems of the types XX/XY and ZZ/ZW, respectively (Arai, 2011).

To date, 45 species of the Bagridae family have been cytogenetically studied, and although variations ranging from $2 n=44$ to $2 n=80$ have been reported, $2 n=56$ is the predominant diploid number. The karyotype formulae for the 9 species analyzed (Table 1) show the variation found in the number of $\mathrm{m}, \mathrm{sm}$, and st/a chromosomes, even within the same genus. In the genus Hemibagrus, most species were $2 \mathrm{n}=58$, excluding $H$. wyckii $(2 \mathrm{n}=62)$. However, there were differences in the number of mono-armed and bi-armed chromosomes. H. filamentus and H. nemurus are closely related based on similarities in their karyotypes. $H$. filamentus has a larger number of $\mathrm{m}$ chromosomes compared to $H$. nemurus, while $H$. nemurus has a larger number of mono-armed chromosomes compared to H. filamentus. Both species are considered to be a species complex. Comparative analysis between the 3 genera in the Bagridae family revealed that the genus Hemibagrus has the most primitive karyotype, mainly because of the occurrence of a high number of mono-armed chromosomes (Sharma and Tripathi, 1986). 


\section{Physical chromosome mapping of 5S and 18S rDNA sequences}

The species analyzed provided clear results concerning the number and location of the ribosomal sites in the chromosomes. However, the number and distribution of the $18 \mathrm{~S}$ and $5 \mathrm{~S}$ rRNA genes were not conserved among the species.

Our results demonstrated that the distribution of $18 \mathrm{~S}$ rDNA is less variable than that of $5 \mathrm{~S}$ rDNA among the species analyzed. 18S rDNA clusters were mostly located at terminal regions in the bagrids, except in $H$. wyckii and P. siamensis, which belong to distinct genera. Among the 3 genera analyzed, Mystus was the most conservative regarding the number and position of $18 \mathrm{~S}$ rDNA clusters. Comparative analysis between the distribution of rDNA clusters in the Hemibagrus and Mystus genera revealed higher levels of variation in the former (Figure 3). Thus, although the genus Mystus showed greater diversity of karyotypes among its species (possibly due to the occurrence of macro-chromosomal rearrangements), the genus Hemibagrus exhibited greater dynamism at a microgenomic level, at least with regards to rRNA genes.

By contrast, the distribution pattern of the 5S rDNA sites varied from 1-5 pairs of chromosomes among the species analyzed. 5S rDNA genes were located in a single pair of chromosomes in $H$. wyckioides, M. atrifasciatus, M. bocourti, M. multiradiatus, M. mysticetus, and $P$. siamensis, which likely represents an ancestral condition in the group of fishes (Martins and Galetti, 1999; Boroń et al., 2006). By contrast, 5S rDNA signals were revealed in 2, 3, and 5 pairs of chromosomes in H. nemurus, H. wyckii, and H. filamentus, respectively. Multiple loci of minor ribosomal genes have been found in some fishes (Martins and Galetti, 2001; Hatanaka and Galetti, 2004; Rocco et al., 2005); variation in the number of 5S rDNA loci has also been observed among other species, such as the red wolf fish Erythrinus erythrinus, which has more than 20 sites (Cioffi et al., 2010), the cichlid Astatotilapia latifasciata, which has 15 clusters (Poleto et al., 2010) and the cichlid Laetacara dorsigera, which has 14 sites (Nakajima et al., 2012), In general, 5S rDNA loci can be found in the interstitial regions of fish chromosomes, and their pattern may represent an ancestral condition or even some advantage for the genome organization of these sequences (Martins and Galetti, 2001). $H$. wyckioides, M. atrifasciatus, and M. multiradiatus appear to maintain the ancestral location of the $5 \mathrm{~S}$ rDNA loci, while the other genera studied had $5 \mathrm{~S}$ rDNA loci at the terminal positions of the chromosomes.

Variation observed in the distribution of rDNA sites implies a complex microevolutionary pattern that rules the organization of genomes. Ribosomal DNAs can spread throughout the genome, thus creating new rDNA loci, variant rDNA copies, and even associations with other multigene families and transposable elements. The existence of multiple 5S rDNA loci in many chromosome pairs may mean that these clusters have been evolving independently and are represented by different units of $5 \mathrm{~S}$ rDNA (Martins et al., 2002). Thus, the existence of multiple minor ribosomal gene loci appears to represent a derived condition in the evolutionary dynamics of fishes. To date, all species of the genera Mystus and Pseudomystus analyzed, including $H$. wyckioides, share this plesiomorphic condition for this character, whereas $H$. nemurus, $H$. wyckii, and $H$. filamentus may have undergone a mechanism such as non-homologous crossing-over to give rise to the derived condition of multiple 5S rDNA loci.

All species of the Bagridae family analyzed, except $H$. wyckii, showed the location of major and $5 \mathrm{~S}$ ribosomal genes in different pairs of chromosomes, likely representing the most common situation observed in Bagrid fishes, just as it does in vertebrates (Martins and 
Galetti, 2000). It has been suggested that as the transcription of these 2 ribosomal gene families takes place through 2 distinct RNA polymerases, these functional differences require different physical locations. Gene conversion and unequal crossing-over act as important evolutionary processes to maintain gene sequences repeated in tandem arrays (Dover, 1989), and these mechanisms may be more efficient if the 2 clusters are separated. This may also explain why most vertebrates maintain this configuration. However, $H$. wyckii is the only species of the Bagridae family in which the 2 ribosomal genes are co-located, a scarce situation among fishes that has been reported in some species such as Prochilodus lineatus (Jesus and MoreiraFilho, 2003), Prochilodus argenteus (Hatanaka and Galetti, 2004), Salmo salar (Pendás et al., 1994), Oncorhynchus mykiss (Morán et al., 1996), fish of the sturgeon family (Fontana et al., 2003), and others (Cross et al., 2006; Marquioni et al., 2013).

The extensive variation in the number and chromosomal position of rDNA clusters observed among the Bagridae genera analyzed is likely related to the intense evolutionary dynamics of repeated units of rDNA that generate divergent patterns of chromosomal distribution, even among closely related species. The genomic organization and evolution of rRNA genes appear to be governed by a combination of birth-and-death and concerted evolutionary mechanisms, which may explain the observed patterns of chromosomal distribution of rDNA clusters among related species (Pinhal et al., 2011).

\section{CONCLUSIONS}

In summary, the distribution of repetitive DNA sequences provided novel, useful information for understanding the evolutionary relationships between Bagridae fishes. The extensive variation in the number and chromosomal position of rDNA clusters observed among these Bagridae species appears to be related to the intense evolutionary dynamics of rDNA repeated units that generate divergent patterns of chromosomal distribution, even among closely related species. Further studies, including the development of new chromosomal markers and a robust phylogeny for this group, will provide additional information regarding the relationship between the Bagridae species.

\section{ACKNOWLEDGMENTS}

Research supported by the Development and Promotion of Science and Technology Talents Project (DPST) of Thailand, by the Molecular Cytogenetics Laboratory, Institute of Human Genetics, Friedrich-Schiller University, Jena, Germany, and by the Brazilian Agency FAPESP (Fundação de Amparo à Pesquisa do Estado de São Paulo).

\section{REFERENCES}

Arai R (2011). Fish Karyotype - a Check List. Springer, Tokyo.

Boron A, Ozouf-Coastaz C, Coutanceau J-P and Woroniecka K (2006). Gene mapping of 28S and 5S rDNA sites in the spined loach Cobitis taenia (Pisces, Cobitidae) from a diploid and a diploid-tetraploid population. Genetica 128: 71-79.

Cioffi MB and Bertollo LAC (2012). Distribution and Evolution of Repetitive DNAs in Fish. In: Repetitive DNA (GarridoRamos MA, ed.). Karger: Genome Dyn, Basel, 197-221.

Cioffi MB, Martins C and Bertollo LAC (2009). Comparative chromosome mapping of repetitive sequences. Implications for genomic evolution in the fish, Hoplias malabaricus. BMC Genet. 10: 34.

Cioffi MB, Martins C and Bertollo LA (2010). Chromosome spreading of associated transposable elements and ribosomal DNA in the fish Erythrinus erythrinus. Implications for genome change and karyoevolution in fish. BMC Evol. Biol. 
10: 271.

Cross I, Merlo A, Manchado M, Infante C, et al. (2006). Cytogenetic characterization of the Solea senegalensis (Teleostei: Pleurenectiformes. Soleidae): Ag-NOR, (GATA)n, (TTAGGG)n and ribosomal genes by one-color and two-color FISH. Genetica 128: 253-259.

Das JK and Khuda-Bukhsh AR (2007). Preponderance of GC-rich sites in silver-stained nucleolus organizing regions of Rita rita (Hamilton) and Mystus gulio (Hamilton) (Bagridae, Pisces), as revealed by chromomycin A3-staining technique and scanning electron microscopic studies. Genet. Mol. Res. 6: 284-291.

Donsakul T (2000). Chromosome Study on Three Species of Bagrid Catfishes, Mystus albolineatus, M. wolffii and Heterobagrus bocourti, from Thailand. In: Proceedings of the 38th Kasetsart University Annual Conference: Fisheries and Science. Kasetsart University, Bangkok, 217-226.

Donsakul T (2001). Chromosome Study on Four Species of Bagrid Catfishes, Mystus nemurus, M. wyckii, M. wyckioides and M. singaringan, from Thailand. In: Proceedings of the 39th Kasetsart University Annual Conference: Fisheries and Science. Kasetsart University, Bangkok, 209-219.

Donsakul T (2002). Chromosome Study on Four Species of Bagrid Catfishes, Mystus mysticetus, Leiocassis siamensis, Bagrichthys macropterus, and B. macracanthus, from Thailand. In: Proceedings of the 40th Kasetsart University Annual Conference: Animal, Fisheries and Science. Kasetsart University, Bangkok, 681-691.

Dover GA (1989). Linkage disequilibrium and molecular drive in the rDNA gene family. Genetics 122: 249-252.

Ferraris CJ (2007). Checklist of catfishes, recent and fossil (Osteichthyes: Siluriformes), and catalogue of Siluriform primary types. Zootaxa 141: 1-628.

Fontana F, Lanfredi M, Congiu L, Leis M, et al. (2003). Chromosomal mapping of 18S-28S and 5S rRNA genes by twocolour fluorescent in situ hybridization in six sturgeon species. Genome 46: 473-477.

Hatanaka T and Galetti PM (2004). Mapping of the 18S and 5S ribosomal RNA genes in the fish Prochilodus argenteus Agassiz, 1829 (Characiformes, Prochilodontidae). Genetica 122: 239-244.

Jesus CM and Moreira-Filho O (2003). Chromosomal location of 5S and 18S rRNA genes in Prochilodus lineatus (Characiformes, Prochilodontidae). Caryologia 56: 281-287.

Kavalco KF, Pazza R, Bertollo LA and Moreira-Filho O (2005). Karyotypic diversity and evolution of Loricariidae (Pisces, Siluriformes). Heredity 94: 180-186.

Kim DS, Park EH, Kim JS (1982). Karyotypes of nine species of the Korean catfishes (Teleostomi: Siluriformes). Korean J. Genet. 4: 57-68.

Levan A, Fredga K and Sandberg AA (1964). Nomenclature for centromeric position on chromosomes. Hereditas 52: $201-220$

Linder S (2002). The Catfishes of Asia Series. Part 1: Family Bagridae. Available at [http://www.planetcatfish.com/ shanesworld/shanesworld.php?article_id=185]. Accessed June 17, 2011.

Long EO and Dawid IB (1980). Repeated genes in eukaryotes. Annu. Rev. Biochem. 49: 727-764.

Magtoon W and Donsakul T (2009). Karyotypes of Five Bagrid Catfishes (Family Bagridae): Mystus multiradiatus, M. castaneus, M. atrifasciatus, Batasio havmolleri and Sperata acicularis from Thailand. In: Proceedings of the 47th Kasetsart University Annual Conference, Kasetsart, Fisheries. Kasetsart University, Bangkok, 328-336.

Marquioni V, Bertollo LA, Diniz D and Cioffi MB (2013). Comparative chromosomal mapping in Triportheus fish species. Analysis of synteny between ribosomal genes. Micron 45: 129-135.

Martins C and Galetti PM (1999). Chromosomal localization of 5S rDNA genes in Leporinus fish (Anostomidae, Characiformes). Chromosome Res. 7: 363-367.

Martins C and Galetti PM (2000). Conservative distribution of 5S rDNA loci in Schizodon (Pisces, Anostomidae) chromosomes. Chromosome Res. 8: 353-355.

Martins C and Galetti PM (2001). Organization of 5S rDNA in species of the fish Leporinus: Two different genomic locations are characterized by distinct non transcribed spacers. Genome 44: 903-910.

Martins C, Wasko AP, Oliveira C, Porto-Foresti F, et al. (2002). Dynamics of 5S rDNA in the tilapia (Oreochromis niloticus) genome: repeat units, inverted sequences, pseudogenes and chromosome loci. Cytogenet. Genome Res. 98: 78-85.

Martins C, Ferreira IA, Oliveira C, Foresti F, et al. (2006). A tandemly repetitive centromeric DNA sequence of the fish Hoplias malabaricus (Characiformes: Erythrinidae) is derived from 5S rDNA. Genetica 127: 133-141.

Morán P, Martinez JL, Garcia-Vazquez E and Pendas AM (1996). Sex chromosome linkage of 5S rDNA in rainbow trout (Oncorhynchus mykiss). Cytogenet. Cell Genet. 75: 145-150.

Nakajima RT, Cabral-de-Mello DC, Valente GT, Venere PC, et al. (2012). Evolutionary dynamics of rRNA gene clusters in cichlid fish. BMC Evol. Biol. 12: 198.

Nanda I, Schartl M, Feichtinger W, Schlupp I, et al. (1995). Chromosomal evidence for laboratory synthesis of triploid hybrid between the gynogenetic teleost Poecilia formosa and its host species. J. Fish Biol. 47: 619-623.

Genetics and Molecular Research 13 (4): 9533-9542 (2014) 
Nelson JS (2006). Fishes of the World. 4th edn. John Wiley and Sons, Inc., New York.

Pendás AM, Moran P, Freije JP and Garcia-Vazquez E (1994). Chromosomal mapping and nucleotide sequence of two tandem repeats of Atlantic salmon 5S rDNA. Cytogenet. Cell Genet. 67: 31-36.

Pinhal D, Yoshimura TS, Araki CS and Martins C (2011). The 5S rDNA family evolves through concerted and birth-anddeath evolution in fish genomes: an example from freshwater stingrays. BMC Evol. Biol. 11: 151.

Pinkel D, Straume T and Gray JW (1986). Cytogenetic analysis using quantitative, high-sensitivity, fluorescence hybridization. Proc. Natl. Acad. Sci. U. S. A. 83: 2934-2938.

Poleto AB, Ferreira IA and Martins C (2010). The B chromosomes of the African cichlid fish Haplochromis obliquidens harbour 18S rRNA gene copies. BMC Genet. 11: 1 .

Rainboth WJ (1996). Fishes of the Cambodian Mekong. Food and Agriculture Organization of the United Nation, Rome.

Rocco L, Costagliola D, Fiorillo M, Tinti F, et al. (2005). Molecular and chromosomal analysis of ribosomal cistrons in two cartilaginous fish, Taeniura lymma and Raja montagui (Chondrichthyes, Batoidea). Genetica 123: 245-253.

Rosa KO, Ziemniczak K, Barros AV, Nogaroto V, et al. (2012). Numeric and structural chromosome polymorphism in Rineloricaria lima (Siluriformes: Loricariidae): fusion points carrying 5S rDNA or telomere sequence vestiges. Rev. Fish Biol. Fish. 22: 739-749.

Sharma OP and Tripathi NK (1986). Karyotypic diversity in genus Mystus (Bagridae: Pisces). Cytologia 51: 1-9.

Vidthayanon C (2005). Handbook of Freshwater Fish. 2nd edn. Sarakadee Press, Bangkok. 